\title{
Institutional and Social Factors Affecting the Acceptance of Family Planning Concept in Jeruklegi, Cilacap, Indonesia
}

\author{
Anisa Sevi Oktaviani 1), Pawito 2), Uki Retno Budihastuti 3) \\ 1)School of Midwifery, Graha Mandiri, Cilacap, Indonesia \\ 2)Faculty of Social and Politics Sciences, Universitas Sebelas Maret \\ 3)Department of Obstetrics and Genecology, dr. Moewardi Hospital, Surakarta
}

\begin{abstract}
Background: Family planning program is important to address population problem. However, there was some barrier confronting the family planning program. This study was aimed to analyze the institutional and social factors that influence the acceptance of the family planning concept.

Subjects and methods: This was a qualitative study with interactive analysis of a policy conducted in Tritih, Wetan, Jeruklegi, Cilacap. A total of head community empowerment Agency, women empowerment, children protection, family planning in Cilacap regency and extension officers in Tritih Wetan were selected by using snowball sampling. The data collected by in-depth interview, observation, analysis document. The data analyzed with a triangulation, included the collection of data, data presentation, data reduction, and the withdrawal of the conclusion.

Results: The policy of family planning village has not provided significant influence towards the understanding of the concept of family planning society Tritih Wetan, Jeruklegi, Cilacap. Institutional factors against the acceptance of the concept of the family planning can be seen through the success indicator input aspect mentioned in the technical instructions of family planning village. In addition, the factors social, economic, and cultural barriers also affect the implementation of the policy of family planning village.

Conclusion: The effectiveness of the implementation of the policy of family planning village in Tritih Wetan,Cilacap yet effective. While the dominant factor influencing the effectiveness of the implementation of the policy of family planning village was a factor family planning resource factors, social factors, and cultural factors.
\end{abstract}

Keywords: family planning village, family planning policy

Correspondence:

Anisa Sevi Oktaviani. School of Midwifery, Graha Mandiri, Cilacap, Central Java. Email: anisasevi@gmail.com.

\section{BACKGROUND}

Population problems are still a major obstacle in several developing countries, such as the still high infant mortality rate and maternal mortality rate, low public awareness about reproductive rights, as well as still low practice of counter-sanctions in meeting family planning needs. high. Family Planning (KB) with a CPR (Contraceptive Prevalence Rate) indicator that is the number of family planning participants and unmet need for family planning services contained in MDG's 5b which mentions targets in realizing reproductive health access for all in 2015. Until the end of 2015, from the target what has been determined is to increase the modern method of CPR to $65 \%$ and reduce the unmet need for family planning services to $5 \%$ in 2015 still far from the target. The low rate of CPR is related to the still high unmet need, which is $8.5 \%$ of the number of couples of childbearing age (EFA) with high potential for the occurrence of unwanted pregnancies (KTD). Therefore, 
family planning is a strategic effort in reducing MMR and IMR (Mujiati, 2013).

According to the World Population Data Sheet (2013), Indonesia has a 2.6 Fertility Rate (TFR), and it is still above the ASEAN TFR average, which is 2.4. TFR will tend to increase if contraceptive use is not increased. The challenge for the government and the BKKBN is to reduce the TFR to 2 . In addition, there are differences in the acceptance of national policies in each region and a limited budget requires thinking with a strategy of working across sectors and using an effective budget for optimal family planning, and increasing community participation in synergizing family planning programs with religious and community views that are still contradictory (BKKBN, 2015).

Family planning village has become one of the strategic innovations to be able to implement priority activities of the Population, Family Planning and Family Development Program (KKBPK) by the National Population and Family Planning Board (BKKBN) in a field line involving all Fields within the BKKBN and synergizing with Institutions, work partners, relevant agency stakeholders in accordance with the needs and conditions of the region, and carried out at the lowest level of government (according to the prerequisites for determining the location of the $\mathrm{KB})$ in all districts and cities (BKKBN, 2015).

From the data obtained from the Cilacap Health Office and the Community Empowerment Agency, Women's Empowerment, Child Protection, and Family Planning (Bapermas, PP, PA, KB), Cilacap District can conclude that the strategic issues in family planning programs in Cilacap Regency in 2014 are the achievement of active KB participants (74.15\%) of the existing fertile age couples is still far enough from the conditions of the population to grow in balance, ie $80 \%$ and PUS who delay having children and not want more children but not having KB in the amount of $12.9 \%$ are still far away from an ideal position of $5 \%$ (Dasro, 2014). However, in a preliminary study it was found that the establishment of KB villages in the region did not comply with the technical guidance criteria of the BKKBN.

The purpose of the study is to analyze the factors that influence the effectiveness of the Village Family Planning Policy towards the acceptance of the concept of family planning in Tritih Wetan Village, Jeruklegi District, Cilacap Regency in terms of implementation background, supporting aspects, inhibiting aspects and the results of the implementation of KB Village Policy.

\section{SUBJECTS AND METHOD}

This was a qualitative study on the policy of KB Village; and acceptance of the concept of family planning involves issues of growing knowledge, growing perceptions and attitudes, and acceptance (adoption) of family planning programs, using interactive qualitative research models of policy analysis that examines the effectiveness and efficiency of a policy, including how it is implemented, factors influencing and the obstacles that occur as well as ways to overcome them in the KB Village program in Tritih Wetan Village, Jeruk Legi District, Cilacap Regency.

The sampling technique used was a snowball sampling, which is collecting data from one informant to another informant, increasing until the data are considered to be enough and the answers from the informants do not add references (Djaelani, 2013). The main informant is the Head of the Family Planning Division of Bapernas, PP, PA, KB in Cilacap Regency and Field Extension in Tritih Wetan Village. 
The data was collected by in-depth interviews, direct observation, and document analysis. The data validity in this study used source triangulation. Data analysis used in this study was an interactive model of Miles and Hubberman (1984) in Gunawan 2014, which consists of four steps: data collection, data reduction, data presentation and conclusion drawing.

\section{RESULTS}

Cilacap Regency has 24 Districts in which there are several villages. One sub-district close to the administrative city of Cilacap is Jeruklegi Subdistrict, which consists of 13 villages, with one village being the first example of Central Java Province for other regions related to the Family Planning Program, namely Tritih Wetan Village, especially the Neighborhood Unit IV. Tritih Wetan Village consists of 11 RWs and has a population of 10,226 people. Whereas, the center of KB Village, RW IV, consists of 3 Neighborhood Associations (RT) with a population of from January to June 2016 of 706 people. The declaration of the $\mathrm{KB}$ village was held on 23 January 2016 based on the Decree of the District Head of Cilacap No. 411/58/29/2015 concerning the Determination of Tritih Wetan Village, Jeruklegi District, Cilacap Regency as a Village of Family Planning in Cilacap Regency in 2016 on 31 December 2015.

The main informant and triangulation characteristics can be seen in the following table. Of the several characteristics of the main informants, including education and tenure, there are linkages and are included in intrinsic factors. This is in line with the existing theory that intrinsic factors include age, experience, education, knowledge, skills, attitudes, willingness, health, personality, work motivation, job satisfaction, situation of salary and income greatly affect the quality of human resources (Mangkuprawira, 2007)

From Table 1 and Table 2 regarding the main informants and triangulation informants, it can be concluded that the age of all main informants and triangulation is more than 32 years, with varying educational backgrounds. The working period of both the main informant and the triangulation informants also varied, with different employment status ranging from civil servants to private housewives.

With regard to the influence of village planning policy on the acceptance of the concept of family planning, the data obtained shows the tendency of three important aspects: 1) understanding of KB Village, 2) target established by $\mathrm{KB}$ Village, and 3) change before and after the establishment of KB Village.

Informant understanding of $\mathrm{KB}$ villages varies. Of all the informants, there were three who knew very well the meaning of KB Village and the three informants were policy makers. Unfortunately, this understanding is not followed by the ranks below such as policy implementers and policy targets.

Informants from field line policy implementers and the community also tend not to understand what is meant by $\mathrm{KB}$ villages because of the lack of socialization about $\mathrm{KB}$ villages. This is in accordance with the statement of $\mathrm{T}_{7}$ informants presented as follows:

"Kampung KB yaa.. apa yaa.. ujugujug (tiba-tiba) sih mba pemberitahuannya" enggak ada kumpulan buat sosialisasi, cuma pas pencanangan aja. Tahunya yaa, kampung yang peserta KB nya paling banyak dibandingkan kampung sekitarnya mungkin mba.."(19 Agustus 2016) 
Journal of Health Policy and Management (2016), 1(1): 29-37

https://doi.org/thejhpm.2016.01.01.05

Table 1. The Characteristics of main informant

\begin{tabular}{|c|c|c|c|c|c|}
\hline $\begin{array}{l}\text { Informant } \\
\text { Code }\end{array}$ & Age & Education & Tenure & $\begin{array}{c}\text { Employment } \\
\text { status }\end{array}$ & Note \\
\hline U 1 & $\begin{array}{c}49 \\
\text { years }\end{array}$ & $\begin{array}{l}\text { Bachelor- } \\
\text { Philosophy }\end{array}$ & 5 years & Civil servant & $\begin{array}{l}\text { Head of KB } \\
\text { Bapermas, PP, PA, } \\
\text { KB Kabupaten } \\
\text { Cilacap }\end{array}$ \\
\hline $\mathrm{U} 2$ & $\begin{array}{c}49 \\
\text { years }\end{array}$ & $\begin{array}{l}\text { Bachelor- } \\
\text { Economy }\end{array}$ & 9 years & Civil servant & $\begin{array}{l}\text { Field extension } \\
\text { officer of KB (PLKB) }\end{array}$ \\
\hline
\end{tabular}

Table 2.The Characteristics of triangulation informants

\begin{tabular}{|c|c|c|c|c|c|}
\hline $\begin{array}{c}\text { Informant } \\
\text { Code }\end{array}$ & $\begin{array}{c}\text { Age } \\
\text { (years) }\end{array}$ & Education & Occupation & Note & Tenure \\
\hline $\mathrm{T} 1$ & & $\begin{array}{c}\text { Post } \\
\text { graduate of } \\
\text { Management }\end{array}$ & $\begin{array}{c}\text { Head of UPT KB } \\
\text { Education of Jeruk } \\
\text { Legi District }\end{array}$ & $\begin{array}{l}\text { Head of UPT KB } \\
\text { Education }\end{array}$ & \\
\hline $\mathrm{T} 2$ & 49 & $\begin{array}{l}\text { Graduate of } \\
\text { Economy }\end{array}$ & $\begin{array}{l}\text { Village head of } \\
\text { Tritih Wetan } \\
\text { District Jeruk Legi }\end{array}$ & Head of Village & 6 years \\
\hline $\mathrm{T}_{3}$ & 48 & SHS & TNI & Head village IV & 1 year \\
\hline $\mathrm{T} 4$ & 57 & SHS & Pegawai Kelurahan & Head village o1(IV) & 1 year \\
\hline $\mathrm{T}_{5}$ & 44 & SHS & Farmer & $\begin{array}{l}\text { Head of family } \\
\text { planning } \\
\text { coordinator }\end{array}$ & 6 month \\
\hline T6 & 32 & Diploma 3 & Village Midwife & Bidan Desa & 5 year \\
\hline $\mathrm{T}_{7}$ & 55 & SHS & Midwife & Cadre & 20 year \\
\hline $\mathrm{T} 8$ & 41 & SHS & Midwife & Cadre & 7 year \\
\hline T9 & 45 & SHS & Midwife & $\begin{array}{c}\text { Women of } \\
\text { childbearing age }\end{array}$ & \\
\hline T10 & 45 & $\begin{array}{l}\text { Primary } \\
\text { school }\end{array}$ & Midwife & $\begin{array}{c}\text { Women of } \\
\text { childbearing age }\end{array}$ & \\
\hline T11 & 37 & JHS & Midwife & $\begin{array}{l}\text { Women of } \\
\text { childbearing age }\end{array}$ & \\
\hline
\end{tabular}

Other cadres also complained that there was no socialization from related institutions about $\mathrm{KB}$ villages. Here are some results of interviews with $\mathrm{T} 8$ informants,

"Kampung KB dibentuk disini karena wilayah sini peserta KB nya paling banyak daripada wilayah $R W$ ato desa lain mungkin mba.. kalo alasan sebenarnya kurang paham lho, karena enggak ada sosialisasi dan mesti wilayah ini terus yang dijadikan percontohan. Kemaren dipilih untuk percontohan Kampung Sehat, Kampung Hijau. Sini terus lah mba..kebanyakan job (pekerjaan) jadinya.. hehe” (20 Agustus 2016)
Establishment of $\mathrm{KB}$ villages that meet the criteria can facilitate implementation and evaluation of policies. Changes before and after the establishment of the KB Village can also be more felt by policy targets. However, in reality, the implementers of field line policies tend to not understand the direction and target of the establishment of KB Village in Tritih Wetan Village. Whereas, according to the remarks by the U1 Informant as the Head of KB, the guidelines or guidelines are only technical instructions from the Center and have been socialized to the villages of the KB in Tritih Wetan village. 
The confusion over the availability of technical guidelines and guidebooks causes targets from $\mathrm{KB}$ villages to be understood from policy makers to policy targets that are not optimal. Some important actors in the implementation of the policy do not understand which ones the targets are, even some do not understand what the target is. The U1 informant restated to answer the research question about the target of $\mathrm{KB}$ Village. Here's the statement.

"Target dari petunjuk teknis Pusat kurang khusus atau kurang spesifik lah, yaa itu tadi, mungkin skala nya Nasional jadi kajiannya belum matang istilahnya. Akhirnya tim saya maksudnya dari Kabupaten mencoba membuat target pelaksanaan yang tertulis dalam tujuan khusus di petunjuk teknis yaitu pencapaian kesertaan ber KB mencapai 80\% dengan metode kontrasepsi jangka panjang minimal $40 \%$, menurunkan unmetneed sampai 5\%, TFR sebesar 2.1." (22 Juli 2016)

The target which was not understood was also experienced by policy implementers in the field line. If the implementers did not know the target of the policy, how the policy can be implemented properly to achieve the objectives, and how the actors and implementers of the policy can run synergistically for the same purpose. This question was based on the following T8 Informant as a cadre:

"Target ya mba..palingan slogan 2 anak cukup itu aja mba..biar semua anaknya 2 aja." (19 Agustus 2016)

"Oh the target, well the 2 children slogan is enough, so that all the residents have two kids." (Augustus 19th, 2016)

Some of the things that have been explained above such as lack of understanding of the meaning and target of FP villages tend to affect the changes that occurred before and after the establishment of FP Village. This can be seen through the achievement of the success indicators of the policy implementation process based on: a) Increasing the frequency and quality of advocacy activities and IECs experiencing constancy; b) Improving the quality of family planning services that were increased in terms of facilities and infrastructure but no changes in the way of providing the information; c) Periodic meetings of activity groups became more integrated in one predetermined place, namely at the Head of Cadre's house. However, the implementation of activities was still carried out once per month and there were no specific activities to discuss the family planning; d) Coverage of family planning programs actually decreased as shown in table 3 .

Institutional factors in the implementation of the FP Village policy in Tritih Wetan Village, Jeruklegi District, Cilacap Regency, were related to the number of FP workers (PLKB/PKB) in the FP Village area which only consisted of 1 person, and it did not fulfill all the target groups in implementing a policy. Although assisted by the heads of activity groups and cadres, activities have not yet focused on mobilizing the participation of family planning programs. The unavailability of budget for the KKBPK program operations from the APBD/RGB and APBN/TIB made the cadre to take the initiative to make monthly contributions, and the residents' contributions through regular monthly meetings. The availability of operational facilities, both contraception and other supporting facilities was relatively adequate. The disadvantage was in the availability of a clear guidebook or guidebook which contained the targets. 
Table 3. The Coverage of Output Indicators

\begin{tabular}{|c|c|c|c|c|}
\hline \multirow[t]{2}{*}{ Indicators } & \multicolumn{4}{|c|}{$\begin{array}{c}\text { Achievements (number of women } \\
\text { reproductive age and \%) }\end{array}$} \\
\hline & before & $\%$ & after & $\%$ \\
\hline The Number of women reproductive age & 109 & 100 & 117 & 100 \\
\hline $\begin{array}{l}\text { Active FP Members (women reproductive } \\
\text { age) }\end{array}$ & 89 & 81.65 & 77 & 65.81 \\
\hline Long Term Contraceptive Method (LTCM) & 36 & 33.03 & 32 & $27 \cdot 35$ \\
\hline $\begin{array}{l}\text { Men with Family Planning from the Total FP } \\
\text { Participants }\end{array}$ & $\mathrm{O}$ & $\mathrm{O}$ & $\mathrm{O}$ & $\mathrm{O}$ \\
\hline Unfulfilled Needs & 20 & 18.35 & 32 & 18.35 \\
\hline 5 Pregnancy & 0 & 0 & 6 & 0.51 \\
\hline
\end{tabular}

The dominant social supporting factor in the participation of family planning programs came from husband's support. This was supported by several statements from informants related to the reasons for using contraceptive methods and the reason for stopping the use of contraceptive because the condom made the husband felt uncomfortable, as revealed by the following T10 informant,

"Pernah menggunakan kontrasepsi kondom tetapi tidak nyaman, dan suami menganjurkan untuk KB dengan pengaturan sendiri. $K B$ lainnya takut pengaruh hormon." (2O Agustus 2016)

"We have used condom contraceptive but it was not comfortable, and my husband suggested to FP with our own control. We did not use other FP because I am afraid of hormone influence." (August 2oth, 2016)

Economic factors have little influence on policy targets which the majority have middle to upper economic status, added with the holding of family planning safaris so that people could participate for free. This factors tend to be more influential on the performance of policy implementers (PLKB and cadres) because without adequate budget support, the performance would not run effectively in achieving policy goals and objectives. This was marked by the frequency and quality of giving infor- mation about family planning in the same way as before the FP Village was formed.

Cultural factors that most affected the community participation in family planning programs include the belief in a particular religion that was still pro-contra for the implementation of FP programs. The term "haram" if they showed their genitals was a sign of a strong belief to not having FP, especially LTCM.

\section{DISCUSSIONS}

Cilacap Regency which has a vision to realize a prosperous Cilacap evenly, was very concerned in controlling the population growth rate through family planning programs, because in terms of population, public welfare would be more easily realized if the existing family has implemented a small family pattern with an average birth of 2 children which would lead to the balanced population growth condition in Cilacap.

Revitalizing the management of the field-line family planning program was one of the breakthroughs for holding up family planning programs throughout the Cilacap Regency, by providing the widest possible opportunity for the community to participate in managing family planning programs at the line field level. For this reason, a public policy was established on the establishment of FP Village which was a 
village/urban area unit that described the high accuracy of the data, the participation of community leaders and the participation of the community to be active in the activities. The implementation of this policy was expected to have a positive influence on the acceptance of the concept of family planning by the community in RW IV, Tritih Wetan Village, Jeruklegi District, Cilacap Regency.

The policy of FP Village has not been implemented effectively in influencing the acceptance of the concept of Family Planning. Three important aspects that illustrated the conclusions were 1) the understanding of FP Village, 2) the target was established in FP Village, and 3) changes before and after the establishment of FP Village. First, an understanding of FP villages was only at the level of policymaking actors because of the lack of sociallization at the level of community leaders and implementing the policies. This was in line with Edwards' theory, mentioning that communication factor was one of the factors that affect the success and failure in policy implementation. Information about policies need to be conveyed to policy makers in order to understand the content, goals, direction, and target groups, so that matters relating to policy implementation can be prepared by policy makers, therefore, the policy implementation process could run effectively and in accordance with the policy objectives (Misroji, 2013).

Likewise, the target of the FP Village was established, the lack of understanding of the target and coordination tend to cause the performance of the policy implementer and community participation not to run synergistically to achieve the goal. From there, changes before and after the FP Village were not felt by the implementers or policy targets. The prevalence of treatment patterns and frequency of giving infor- mation indicated this condition. These findings were not in line with the theory postulated by Dasro on his observations in 2014. According to Dasro, Village Family Planning was a renewal of the management of family planning programs at the village/sub-district level which was able to foster high awareness and participation and accelerated the culture of good family planning from the FP management and participants so that the family planning program could be implemented optimally (Dasro, 2014).

Institutional factors that affected the implementation of FP Village policy in Tritih Wetan Village, Jeruklegi District, Cilacap Regency were related to the proportion of proportionality FP personnel (PLKB/PKB), budget availability for KKBPK programs from APBD/RGB and APBN/TIB and other funding sources such as PNPM, Village Fund Budget (VFB), Hope Family Program (HFP), community health insurance, regional health insurance, availability of operational facilities, both contraception and other supporting facileties. This was in line with a study done by Merrynce in 2013 which stated that the dominant factors affecting the effectiveness of the implementation of family planning programs were communication and resource factors, the resource factors focused on the availability of FP extension counselors, the budget for program implementtation and the facilities of family planning devices. The limited human resources of extension workers was a major obstacle to deliver the information to the public (Merrynce, 2013).

Social support factors in the participation of family planning programs came from husband's support and information and support from field line policy implementers such as PLKB, village midwives, and cadres. Mattila and Wirtz's research in 
2008 showed the similar results, the study stated that the social factors were the surrounding community and health personnel, and suggested that social factors could provide stimulation and choices to implement or ignore the policies which were implemented in a government on someone's behavior.

Economic factors have little influence on policy targets which the majority have upper middle economic status, added with the holding of family planning safaris and the existence of BPJS programs, so that the community could participate for free. This was in line with the statement of Trisnawarman in 2008 which stated that elections (in this case was contraceptives) which were carried out rationally was the use of contraception voluntarily without coercion, in terms of health, social, and economic conditions of each partner (Trisnawarman., 2008). Supposedly, PUS who have middle and upper economic factors and were supported by the government could use contraceptives more easily, but in reality, people tend to be reluctant to use the contraceptives. These economic factors tend to be more influential on the performance of policy implementers (PLKB and cadres) because without adequate budget support, performance would not work effectively in achieving policy goals and objectives. According to Edwards, to ensure the implementation of a public policy, factors related to budget were needed to implement policies for effectiveness in achieving goals and objectives. Including budget for implementing the policies.

While cultural factors that affect community participation in FP programs include belief in a particular religion which was still pro-contra for the implementation of FP programs, as well as belief in the opinion of indigenous medical practitioner who said that the informants could not have any child, therefore, the informants (WRA) felt that they did not need contraception.

According to the BKBN in 2015, generally, the success of FP Village was influenced by 5 (five) main factors, namely: 1) Strong commitment from policy actors; 2) Intensity and integration across sectors related to public opinion about KKBPK Program; 3) Optimizing facilities and supporting partners; 4) The enthusiasm and dedication of program managers throughout the regional level as well as FP field line officers (PKB/PLKB), and 5) active community participation (BKKBN, 2015). In this study, another important factor was the cultural factors in society that were still looking for ways to unite with the scientific thinking of society.

This study concluded that the implementation of the Family Planning Village Policy in Tritih Wetan Village, Jeruklegi District, Cilacap District has not been effective. While the dominant factors which influenced the effectiveness of the implementation of village planning policies were communication, resource, social, and cultural factors.

\section{REFERENCES}

BKKBN (2015). Petunjuk Teknis Kampung Keluarga Berencana. Jakarta: BKKBN.

Dasro (2014). Membangun Kampung Kencana Melalui Revitalisasi Pengelolaan Program Keluarga Berencana Lini Lapangan. Semarang: Pemerintah Provinsi Jawa Tengah Badan Pendidikan dan Pelatihan.

Djaelani AR (2013). Teknik Pengumpulan Data dalam Penelitian Kualitatif. Majalah Ilmiah Pawiyatan XX(1).

Mattila AS, Wirtz J (2008). The Role of Store Environmental Stimulation and Social Factors on Impulse Purchasing. 
Oktaviani et al./ Institutional and Social Factors Affecting the Acceptance

Journal of Services Marketing 22(7): 562-567.

Merrynce, Ahmad H (2013). Efektivitas Pelaksanaan Program Keluarga Berencana. Jurnal Kebijakan Publik, 4(1): 1-118.

Misroji (2014). Analisis Faktor-faktor yang Mempengaruhi Implementasi Kebijakan Penyebaran Informasi Publik Mengenai Depok Cyber City pada Diskominfo Kota Depok. Tesis. Program
Pascasarjana (S2) Universitas Esa Unggul Jakarta.

Mujiati I (2013). Pelayanan Keluarga Berencana Pasca Persalinan dalam Upaya Mendukung Percepatan Penurunan Angka Kematian Ibu. Buletin Jendela Data \& Informasi Kesehatan, 2(2).

Trisnawarman E (2008). Sistem Penunjang Keputusan Pemilihan Metode/ Alat Kontrasepsi 